\title{
Genç Nüfusun Seçim Dönemlerinde Medya Kullanımı: Türkiye 31 Mart 2019 Yerel Seçimleri
}

\author{
Faruk Temel (Dr. Öğr. Üyesi) \\ Erciyes Üniversitesi İletişim Fakültesi \\ faruktemel @erciyes.edu.tr \\ Başvuru Tarihi: 18.04.2020 \\ Yayına Kabul Tarihi: 06.06.2020 \\ Yayınlanma Tarihi: 24.07.2020 \\ https://doi.org/10.17680/erciyesiletisim.722801
}

\section{Öz}

Siyasal iletişim süreçlerinde seçim kampanyaları, seçmen ve politikacıların yüksek düzeydeki teması bakımından önem arz etmektedir. Seçim kampanyasında siyasi partiler, çeşitli yöntemlerle seçmene ulaşmak ve seçmenin oy kararını etkilemek amacıyla bir takım faaliyetler yürütmektedir. Bu faaliyetler arasında medya etkinlikleri önemli yer tutmaktadır. Medya, seçmen ve aday/siyasi parti arasında mesaj akışını sağlaması bakımından önemli bir pozisyondadır. Bu çerçevede seçim dönemlerinde genç nüfusun medya kullanım düzeylerini, medyanın karar alma süreçlerindeki rolünü belirlemek ve seçmenin bilgi kaynakları arasındaki ilişkilerin tespit edilmesi çalışmanın amacını oluşturmaktadır. Araştırma kapsamında, 31 Mart 2019 Mahalli İdareler Seçimleri sırasında, Türkiye'de eğitim gören çoğunluğu 17 ve 26 yaş aralığındaki 550 üniversite öğrencisine yönelik yüz yüze anket uygulaması gerçekleştirilmiştir. Anket uygulamasıyla, katılımcıların seçim döneminde medya ile ilişkileri, siyasal bilgi kaynakları, oy verme tercihinde etkili faktörler ölçümlenmiştir. Çalışma sonucunda, seçim döneminde bilgi kaynakları arasındaki internetin ve televizyonun gençler tarafından en fazla takip edilen medya araçları arasında yer aldığı, sosyal medyanın da genç nüfusun karar alma süreçlerinde önem taşıyan bir mecra olduğu tespit edilmiştir. Aynı zamanda seçim sürecinde, daha çok geleneksel bilgi kaynakları arasında yer alan aile ve yakın çevreden edinilen bilgilerle, medyadan edinilen bilgiler arasında bir etkileşimin söz konusu olduğu sonucuna ulaşılmıştır.

Anahtar Kelimeler: Siyasal İletişim, Seçim Kampanyaları, Medya, Genç Nüfus, Üniversite Öğrencileri.

Bu çalışma, Erciyes Üniversitesi Sosyal ve Beşeri Bilimler Etik Kurulu'nun 24.03.2020 tarihli toplantısında görüşülmüş ve etik açıdan uygun bulunmuştur. 


\title{
Media use of the Young Population in The Election Periods: March 31, 2019 Local Elections in Turkey
}

\author{
Faruk Temel (Asst. Prof. Dr.) \\ Erciyes University Faculty of Communication \\ faruktemel @erciyes.edu.tr
}

Date Received: 18.04.2020

Date Accepted: 06.06.2020

Date Published: 24.07.2020

https://doi.org/10.17680/erciyesiletisim.722801

\begin{abstract}
In political communication processes, election campaigns are important for the high level of contact between voters and politicians. In the election campaign, political parties carry out some activities in order to reach the voters through various methods and influence the voters' decision. Media activities occupy an important place among these activities. The media has an important position in ensuring the flow of messages between the voter and the candidate/political party. In this framework, the purpose of the study is to determine the media use levels of the young population, the role of the media in the decision-making processes and to determine the relations between the information sources of the voters during the election periods. Within this study, during the March 31, 2019, Local Government Elections, the majority of those studying in Turkey in the age range of 17 and 26550 university students face to face interviews were conducted for the application. With the application of the questionnaire, the influences of the participants with the media, political information sources, and voting preferences were measured during the election period. As a result of the study, it was determined that the internet and television among the information sources were among the media tools most followed by the youth during the election period, and social media was an important medium in the decision-making processes of the young population. At the same time, in the selection process, it was concluded that there is an interaction between the information obtained from the family and the immediate environment, which are among the traditional sources of information, and the information obtained from the media.
\end{abstract}

Keywords: Political Communication, Election Campaigns, Media, Young Population, University Students. 


\section{Giriş}

Demokratik toplumlarda kamunun siyasal tercihlerini yansıttığı ve siyasal katılımın gerçekleştiği temel eylem biçimlerinden birisi seçimlerdir. Siyasal aktörler seçim dönemlerinde karar anı gelinceye kadar çeşitli yöntem ve tekniklerle seçmenleri etkilemeye çalışırken, siyasal aktörlerin aktivitelerinin yanı sıra seçmenlerin karar belirleme süreçlerinde birçok faktör etkili olmaktadır. Mesajın kaynağı olarak siyasi parti, adayın kendisi, siyasal kimlikler ve mesajın hedefi seçmenlerin demografik özellikleri, ailesi, arkadaş çevresi, ideolojileri gibi unsurlar seçim döneminde karar süreçlerinde etkili olmaktadır.

Siyasal iletişim sürecinin yoğun biçimde işletildiği süreçlerden olan seçim kampanyaları, seçmen ve siyasi partiler arasındaki görünür ve yakın ilişkilerden biri olarak konumlanmaktadır. Oy verme davranıșını istenilen yönde belirlemek adına siyasi partilerin toplantılar, mitingler ve çeşitli araçlarla ulaştığı seçmen de kampanya sürecindeki mesajları değerlendirmektedir. Şüphesiz seçim kampanyası sürecinde adaylar ve seçmen arasında enformasyon akışına aracılık eden medya önemli bir unsurdur. Seçmen ve aday arasında enformasyonun taşıyıcısı pozisyonunda rol alan medya; haber, reklam, fikir empozesini yansıtan içeriklerle (açıkoturum, köşe yazıları) seçmenlerin karar verme süreçlerinde aktif bir rol oynamaktadır. Bu süreçte siyasi aktörlerin medyayı etkin kullanımı gereklilik arz ettiği kadar seçmenlerin de medyayı doğru kullanımı önem taşımaktadır.

Yirminci yüzyılın ikinci çeyreğinde uygulanmaya başlayan seçim kampanyaları, siyasal iletişim literatürünün gelişmesine katkı sağlarken diğer taraftan seçim süreçlerinde medyanın rolüne dönük çalışmaların sayısını da artırmıştır. Seçmenlerin oy tercihinde etkili olan faktörlere ilişkin ve seçim kampanyalarında medyanın rolüne dönük literatürde birçok çalışma yer almaktadır. Siyasal fikirlerle gazete arasında ilişkiyi ortaya koyan araştırmalar, seçim dönemlerinde özellikle televizyonun etkili bir iletişim aracı olduğuna yönelik sonuçlar ortaya koyan çalışmalar ve son dönem araştırmalarda internetin hem ayırt edici özelliklerini yansıtan hem de diğer kitle iletişim araçlarına göre yoğun biçimde kullanıldığını gösteren yayınlar bulunmaktadır(Kalender, 2000; Temel, 2013:24143; Temel, vd. 2014; Balcı, 2016). Bu çerçevede çeşitli zamanlarda, farklı yöntem ve örneklemlerle gerçekleștirilen bu araștırmalar teknolojik ve toplumsal değișime koșut olarak tekrarlanmakta ve bu anlamda değişimleri tespit etmek önem taşımaktadır.

Araştırma kapsamında, seçim süreçlerinde genç nüfusun medya ile ilişkilerini saptamak ve seçim kampanyalarında aile ve yakın çevre ile medya ilişkisi doğrultusunda bilgi kaynaklarının kullanım ve önem düzeylerinin ölçülmesi amaçlanmaktadır. $\mathrm{Bu}$ anlamda Türkiye'de 31 Mart 2019 tarihinde gerçekleştirilen mahalli idareler seçimlerinin kampanya sürecinde genç nüfusun yoğun olarak kümelendiği üniversite öğrencilerine yönelik anket uygulaması neticesinde elde edilen sonuçlar değerlendirilmiștir. Araştırma, nicel bir yaklaşım biçimi olan anket tekniği uygulanarak gerçekleștirilmiştir. Bu bağlamda çalışma, siyasal iletişime ilişkin kavramsal bir çerçeve çizerken, seçim kampanyaları ile medya ilişkilerini açıklamakta ve anket uygulaması sonucunda elde edilen verilerin analizlerini içermektedir.

Araştırma kapsamında; seçim dönemlerinde genç seçmenlerin medya kullanım düzeyi nedir? Karar süreçlerinde medya araçlarına verilen önem düzeyi nedir? Seçim sürecinde takip edilen bilgi kaynakları nelerdir? Bu bilgi kaynaklarına verilen önem derecesi nedir? 
Oy kararının belirlenmesinde etkili olan faktörler nelerdir? Bu faktörler arasındaki ilişki nedir? sorularına cevap aranmaktadır.

\section{Kavramsal Çerçeve}

Siyasal iletişimle ilgili akademik çalışmalar yirminci yüzyılın ilk yarısında başlamıştır. Laswell'in propaganda analizi, Gordon Allport'un ikna çalışması ve Walter Lipmann'ın kamuoyu teorisi siyasal iletişim çalışmalarının ilk örneklerini oluşturmaktadır. Bu çalışmalar, 1900'lerin başında bir çalışma alanı olarak ortaya çıkan sosyal psikoloji araștırmalarından etkilenmiştir (Ryfe, 2001: 408). Siyasal iletişim ve alan araștırmaları iletişim teknolojilerindeki gelişmeler doğrultusunda dönemsel olarak karakteristik değişimlere uğramıştır. Blumler ve Kavanagh’ın (1999: 211-213), siyasal iletişimin değişimine ve araștırmaların seyrine ilişkin yaptıkları dönemselleștirmede; II. Dünya Savaşı sonrasında siyasi partilerin/ ideolojilerin parlak bir dönem geçirdiği ve kitle iletişim araçlarıyla ilişkili olduğu süreç birinci dönemi kapsarken, ikinci dönem, televizyonun domine ettiği bir siyasal iletişim sürecini ve üçüncü dönem de yeni iletişim teknolojilerinin önem kazandığı devreyi içermektedir.

Siyasal iletişim en genel anlamıyla "Siyasal aktörlerin belli ideolojik amaçlarını, belli gruplara, kitlelere, ülkelere ya da bloklara kabul ettirmek ve gerektiğinde eyleme dönüşürmek, uygulamaya koymak üzere çeşitli iletişim tür ve tekniklerinin kullanılarak yapılması" şeklinde tanımlanmaktadır (Aziz, 2007:3-4). Bu çerçevede siyasal iletişim, Laswell'in (1960) kim, kime, hangi kanal aracılığıyla, hangi etkiyle, ne söylüyor şeklinde tanımladığı iletişim sürecini takip eden bir siyasal mesaj akışını içermektedir.

Siyasal iletişim süreci, çok geniş boyutlu, çeşitli aktörlerin birçok mecra üzerinden, muhtelif iletişim aktivitelerini uyguladığı, dinamik bir yapıdır (Başarır, 2019:628). Siyasal iletişim sürecinde siyasal mesaj gönderen kaynak durumundaki kişi, grup, ya da ülke ve temsilcileri siyasal aktör olarak tanımlanmaktadır. Süreç içerisinde güçlerini kabul ettirmeye çalışarak siyasal bir meşruiyet edinmeye çalışan tüm kişi ve kurumlar siyasal aktörler (merkezi hükümetler ve yerel yönetimler, siyasi partiler, sivil toplum kuruluşları, baskı ve menfaat grupları, vatandaşlar)olarak kabul edilmektedir (Özkan, 2004:44).

Siyasal aktörün mesaj gönderdiği, kararlarına ve eylemlerine katılım, destek, onay beklediği siyasal katılım gerçekleștiren unsur hedef kitle şeklinde konumlanmaktadır. Hedef kitle, siyasal aktörün gönderdiği mesaja olumlu ya da olumsuz karşıllk vererek siyasal iletişim sürecinin sonuçlanmasını sağlayan kişi, grup, kurum, kuruluş ya da ülkedir. Siyasal katılım, yalnızca seçimlere indirgenemeyen geniş anlamda oy verme davranışını da içine alan siyasete olan ilgi ve siyasal eyleme kadar giden geniş bir tutum ve etkinlik alanını kapsamaktadır. Seçim dönemlerinde ise siyasal katılma; oy verme, mitinglere katılma, toplantıları izleme, kitle iletişim araçlarıyla ya da yerinde siyasi mesajları takip etme şeklinde belirmektedir (Tokgöz, 2008:177). Siyasal iletişim süreci içerisinde önemli yer tutan seçim kampanyaları, özellikle vatandaşın fiilen siyasal katılım gerçekleştirdiği süreci anlatmaktadır. Seçim kampanyaları ya da seçime dönük gerçekleştirilen siyasal kampanyalar, özellikle medya aracılığıyla adayların toplayabildiği tüm dikkat ve ilgiyi seçim çıkarları için kullandığı arenadır (Tokgöz, 2008:229).

Siyasal katılımı gerçekleștirmesi beklenen hedefe dönük yürütülen siyasal iletişim sürecindeki önemli faktörlerden birisi ise mesajdır. Mesaj, kaynağın niyetini ve niteliğini açıkladığı gibi bu çerçevede siyasal katılımın yönünü de belirleyen söylem ve eyleme dönük içerik şeklinde belirmektedir. 


\section{Seçim Kampanyaları ve Medya İlişkisi}

Seçim kampanyalarına ilişkin araştırma ve uygulamalar, modern demokratik toplumlarla eş zamanlı bir şekilde başlamıştır. 20. yüzyılda yaşanan siyasal ve toplumsal gelişmelerin siyasetin uygulanma ve algılanma biçiminde meydana getirdiği değişiklikler modern seçim kampanyalarının ortaya çıkmasını sağlamıştır (Ünlü, 2018:379). Seçim kampanyaları özellikle kitle iletişim araçlarının kullanılmasıyla siyasal ve toplumsal yaşamda merkezi bir konuma gelmiştir (Tokgöz, 2008:227). Bu durum aslında seçim kampanyaları konusunda dünya genelinde bir benzeşme oluşturmuş ve kitle iletişim araçlarıyla yürütülen kampanya tarzına ilişkin özellikle küreselleşmenin de etkisiyle "Amerikanlaşma" şeklinde eleştirel bir tanımlamayı beraberinde getirmiştir (Özkan, 2004:44-45).

Seçim kampanyaları demokratik toplumlarda siyasi partilerin yönetimde pay sahibi olmak için yarış durumunda olduğu süreçlerde gerçekleşmektedir. Siyasal iletişim sürecinin belki de en yoğun işletildiği dönemi resmeden seçim kampanyaları, devlet yöneticilerini, mecliste yasa yapıcıları, ya da yerel yöneticileri seçmek üzere, ülke çapında ya da yerel bölgelerde yapılan seçimlerde siyasal partilerin gösterdikleri adayların, ilgili yasal düzenlemeler çerçevesinde seçimleri kazanmak üzere yürüttükleri propaganda çalışmalarında kullanılan yöntem ve tekniklerin tümüdür (Aziz, 2007:107).

Seçim kampanyaları, siyasal aktörlerin herhangi bir araç kullanmadan seçmenle bir araya geldiği yüz yüze iletişim şeklinde ya da teknik araçlar vasıtasıyla kurulan aracılı iletişim şeklinde gerçekleşmektedir (Aziz, 2007:48). Günümüzde, seçim kampanyalarında, meydan mitingleri ve daha küçük ölçekte toplantılar, siyasi aktörler tarafından tercih edilmekle birlikte değişen sosyal ve siyasal koşulların da etkisiyle aracılı iletişim, seçim kampanyaları sürecinde yoğunluklu biçimde uygulanmaktadır. Kampanya sürecinde, halkla ilişkiler faaliyetleri, siyasal reklam kampanyaları, kamuoyu yoklamaları, anketler, tanıtım filmleri, afiş, araç giydirmeleri, broşürler, röportajlar, televizyonda tartışma programları, açık oturumlar, internet ve partilere ait web sayfaları, sosyal medya seçmenle aracılı iletişim kurma yolları olarak öne çıkmaktadır (Tunca ve Avtürk Koldaş, 2019: 2800). Bu akış içerisinde siyasi partiler ve vatandaşlar baş aktörler gibi gözükse de, politik kuruluşların tamamı kampanya sırasında etkili unsurlar arasında yer almaktadır. Süreç; baskı grupları, sivil toplum kuruluşları, ticari kuruluşlar, bağışçılar, aktivistler, destekçiler, ittifaklar, medya kuruluşları, medya uzmanları gibi birçok aktörün etkinliğini kapsamaktadır(Strömbäck ve Kiousis, 2014:109).

Seçim kampanyalarında medya aktiviteleri önem taşımaktadır. Siyasal aktörler seçmen kitlesine ulaşmak amacıyla medyayı kullanırken seçmenler de siyasal aktörlerin mesajlarına ulaşmak için medyayı takip etmektedir. Seçim kampanyalarında medya, karşılıklı ilişkinin, aracılanmış iletişimin göstergesi olarak konumlanmaktadır. Medya, kampanyanın etkileyen ve etkilenen aktörlerinin merkezinde yer almaktadır. Siyasi partiler ve vatandaşlar, medya organizasyonunun çıtıtırı ve yorumlamaları olan; haberler, TV tartışmaları, bloglar, web siteleri, güncel olaylar aracılığıyla etkileşim sürecini işletmektedir (McNair, 2011:19). Medya, bütün bu süreçlerde siyasileri halka çevirmekle kalmaz mesajları da kendi siyasetine göre yorumlayarak aktöre dönüşmektedir. Bu çerçevede medyanın siyasi süreçteki konumu eylem ve reaksiyon içeren bir diyalektikliktir. Özellikle seçim zamanlarında parti tercihleri yönünde aktif kampanya yürüten medya kuruluşlarının bazıları bunu siyasi partiler adına açıkça propagandacı bir üslupla gerçekleştirirken, bazıları çeşitli seviyelerde çarpıtma ve sansasyonel nitelikte, çok az bir kısmı ise geniş bir perspektifle mantıklı açıklamalarla 
özetlemektedir (McNair, 2011:43,69). Medyanın bu tutumuna karşılık, bireylerin siyasal kararlar, konular ve sorunlar hakkında edineceği bilgiler ve alacağı haberler kitle iletişim çağında dolaylı hale gelmiştir. Seçmenler, siyasal gündemlerle ilgili doğrudan bilgi sahibi olmak yerine kitle iletişim araçlarının kendilerine hazırladığı çıktılar aracılığıyla fikir edinebilmektedir. Bu durum genel seçmen kitlelerini, siyasal alandaki faaliyetleri, tartışmaları ve siyasi gündemleri kitle iletişim araçlarının diliyle kavrar hale getirmiştir (Damlapinar ve Balcl, 2014:44-45).

Kitle iletişim araçlarıyla siyasal kampanya ilk kez 1907'de gazetelerde seçim haberi şeklinde yer alırken, ABD Başkanı Calvin Coolidge'ın 1924 yılı seçimlerinde radyoda konuşması seçim kampanyasında radyo kullanımına örnek teşkil etmektedir. 1930'da da Başkan Roosevelt ile ilk canlı radyo bağlantısı kurulmuştur(Tokgöz, 2008:234). Bununla beraber medyanın seçim dönemlerinde etkinliğine ilişkin araştırmalar 1950 sonrasına rastlamaktadır. Erken dönem araştırmalarında televizyonun seçim kampanyaları sürecindeki siyasi yayınlarda ve seçmenlere yönelik kampanya konularında ve politik konuşmalardaki etkinliğinin önem kazandığı gösterilmiştir. Nitekim siyaset ve televizyon adeta birbirlerine bağımlı birer unsur olarak belirirken, siyasetin ürettiğini paketleyen televizyon, içerikleri izleyiciye ustalıkla aktardı (akt. Gurevitch vd., 2009: 165-66). Örneğin, ABD 1952 seçimlerinde başkanlığı kazanan Eisenhower'ın televizyonu kullandığı seçim süreci, seçim kampanyalarında TV kullanımının ilk örneğini oluştururken, 1960 ABD başkanlık seçimlerinde ABC ve NBC'nin ortak TV yayını da televizyonla gerçekleştirilen seçim kampanyalarına örnek teşkil etmektedir. Bu seçimlerde Nixon ve Kennedy'nin katıldığı TV programındaki tartışma sonrası, TV'deki performansının büyük orandaki etkisiyle seçimleri Kennedy kazanmıştır (Aziz, 2007:113-114). Bugün televizyonun siyaset sahnesinde aynı şartlarla belirleyici olduğunu söylemek zor görünmektedir (Amerikanınsesi.com, 2020). İnternet Amerikan Yaşamı Projesi kapsamında elde edilen sonuçlara göre 2004'ten 2015'e kadarki süreçte Amerikan devlet başkanlığı seçim kampanyası haberlerine kaynaklık teşkil eden internet kullanımı yüzde 23 oranında artarken televizyon izleme oranı ise yüzde 4 azalmıştır. Bununla birlikte internetin kullanım yüzdesindeki yükselişin seçim kararlarının belirleyicisi olduğunun göstergesi olduğunu söylemek güçtür; daha ziyade medya uzmanlarının, politikacıların ve seçmenlerin sergilediği etkinlik ve etkileşim, seçim kampanyalarının başarısını açığa çıkaran faktörler olarak belirmektedir. Diğer taraftan televizyonun kullanımındaki düşüş ve internetin yükselişi yalnızca siyasal iletişim süreçlerinde değişen medya ekolojisini ve siyasi uygulamalara ilişkin farklılaşmayı göstermektedir (Gurevitch vd., 2009:167,169). İletişim kanallarındaki bu değişimler siyasal kampanyalarda kendisini gösterirken bir anlamda siyasal kültür değişimine doğru yol almaktadır (Paletz ve Lipinski, 1994:15). Siyasal kültürdeki dönüşümü medya özelinde dönemsel olarak da tanımlamak mümkündür. Bu bağlamda 1960 öncesinde radyo, gazete ve kısmen TV kullanımı söz konusuyken, bu dönem medyanın kitle iletişiminde fonksiyonel olmadığı, partilerin mesajlarını mitingler aracılığıyla aktardığı döneme işaret etmektedir (Tunca ve Avtürk Koldaş, 2019:2799). 1970 sonrası dönem özellikle 2000’lere kadar televizyon ile gazetenin ve 2000 sonrası ise internetin seçim kampanyalarında etkili olduğu süreci kapsamaktadır. Bu araçların seçim kampanyaları sürecindeki dönemsel ayrımları, etkiyi birbirlerine devretmelerinin göstergesi değil ancak dönemsel olarak KİA arasındaki çeşitlenen etkileşim süreçlerini yansıtmaktadır.

Günümüzde yeni iletişim teknolojilerinde yaşanan gelişmeler, 21'inci yüzyılın dinamikleri gereği siyasal seçim kampanyalarının doğasını da değişime uğratmıştır. Yeni iletişim 
teknolojileriyle seçmene doğrudan ulaşabilme imkânı, seçim kampanyalarında daha farklı stratejilerin uygulandığı bir süreci zorunlu kılmıştır (Vural Akıncı ve Bat, 2009: 2745). Geleneksel medyaya eklemlenen internet teknolojisine dayalı yeni medya unsurları ile birlikte siyasal bilgilenme sürecinde de bir dönüşüm yaşanmaya başlamıştır. Geleneksel medyanın yapısal özellikleri düşünüldügünde kısıtlayıcı ve tek yönlü iletişim, yeni medya araçlarıyla birlikte çift yönlü ve etkileşime izin veren bir boyuta evirilmiştir (Bal ve Delal, 2019:119). Bu açıdan İnternet, teknik özellikleri ve sosyal ağları kuran özellikleriyle siyasal iletişim alanında sağladığı kolaylıklar neticesinde siyasal katılım düzeyini artıran bir nitelik taşımaktadır (Karaçor, 2009:125). Seçmenlerin siyasal partiler/liderler/adaylar hakkında bilgilendirilmesi, parti programlarının aktarılması ve benimsetilmesi, siyasal aktörlerin çeşitli konular ile ilgili fikir ve çözüm önerilerinin sunulması ve diğer kitle iletişim araçlarında yayınlanan öğelerin yeniden yayınlanmasına imkân veren internet, seçmeni bilgilendirmeyi ve kamuoyu oluşturmayı isteyen siyasal aktörler için, bilgi akışını yönetebilmelerini ve karşılıklı/anında iletişim kurabilmelerini sağladı (Çağlar ve Köklü, 2017:149-50). Tüm bu gelişmeler doğrultusunda, zaman ve mekân sınırlaması olmaksızın, karşılıklılık ve iki yönlü bir bilgi akışına imkân tanıyan, kullanıcıları birer "içerik üreticisi" olarak ön plana çıkaran yapısı sayesinde sosyal ağlar, dünyada ve Türkiye'de kısa sürede, siyasal katılım ve siyasal bilgilenme için önemli bir mecra halini alırken, seçim dönemlerinde politikacıların internete giderek daha fazla ilgi göstermeye başladığı süreci beraberinde getirmiştir (Akyol, 2015:99; Olkun vd., 2018:997; Arklan ve Akgül, 2013)

Bayraktutan ve arkadaşlarının (2014) gerçekleştirdiği çalışmada, internetin, seçim dönemlerinde, seçim için bilgi toplama ve seçim malzemelerinin dağıtımını içeren kampanya faaliyetleri, reklam verme, belli topluluklara ulaşma ve e-posta adreslerinin toplanmasıyla iletişim, seçmenlerin seçim sürecine daha fazla katılımını sağlama amacıyla yürütülen etkinliklerle harekete geçirme, çok sayıdaki kaynaktan az miktarda gelir sağlamayı öngören stratejiler ile kaynak oluşturma işlevlerini yerine getirdiği ortaya konulmaktadır. Kampanya sürecinde medya kontrollü çevrimiçi iletişim araçları ve kullanıcı kontrollü çevrimiçi iletişim araçları kullanılmaktadır. Üçüncü şahısların inisiyatifinde bulunan medya kontrollü çevrimiçi iletişim araçları, haber sitesi ya da blog gibi kampanya sitelerine klyasla daha fazla seçmene ulaşan simgesel içerik ve enformasyon aktarım kanallarıdır. Kullanıcı kontrollü çevrimiçi iletişim araçları ise, Facebook ve Twitter'ı da içine alan çeşitli sosyal ağ uygulamalarını kapsamaktadır (Bayraktutan vd., 2014:2).

İnternetin seçim kampanyalarındaki etkinliği Amerikan başkanlık seçimleri örneğinde incelenmiştir. Demokrat Parti adayı Barack Obama ve Cumhuriyetçi aday John McCain'in yarıştığı 2008 seçimlerinde ilk etapta McCain avantajlı durumdayken, Barack Obama, propaganda kampanyalarında hem interneti hem de televizyonu etkin biçimde kullanarak öne geçti. Obama, sloganlar, siyasi reklamlar, filmler ve vaatlerle medya gösterisi sundu ve Amerikalıları ikna etmeyi başardı(İnce ve Koçak, 2018:48; Kellner, 2011). Diğer taraftan Obama'nın başkanlık seçimleri sırasında bir sosyal medya ekibi oluşturup geçiş dönemindeki sosyal ağ yaklaşımlarıyla çevrimiçi teknolojinin seçim kampanyalarında kullanımına öncülük ettiği söylenebilir(Borins, 2011:85). Yine ABD Başkanlık seçimlerinde bu kez Trump'ın internette yürüttüğü kampanya da dijital alanda etkin iletişim modelinin örneğini sergilemektedir (www.gemius.com.tr, 2020).

İnternetin seçmen açısından da rolünü göstermesi bakımından Türkiye`de 31 Mart 2019>da gerçekleştirilen yerel seçimler sonrası seçim sonucu takip verileri önemli 
görünmektedir. Yerel seçimlerden bir gün sonra 1 Nisan günü Yüksek Seçim Kurulu'nun resmi sitesi ysk.gov.tr 1 milyon 200 bin gerçek ziyaretçiye ulaştı. Gemiusadreal Mart ayı verileri incelendiğinde de Türkiye'de internet kullanıcılarının yüzde 73'ünün bir siyasi parti reklamıyla karşılaștığı görülmektedir (www.gemius.com.tr, 2020).

\section{Türkiye Mahalli İdareler Seçim Sürecinde Üniversite Öğrencilerinin Medya Kullanımı}

\subsection{Araştırma Konusu}

Türkiye'de 31 Mart 2019 tarihinde büyükşehir, il, ilçe ve belde belediye başkanları, il genel meclisi üyeleri, belediye meclis üyeleri, muhtar ve ihtiyar heyeti belirlemek üzere ülke genelinde mahalli idareler seçimleri gerçekleştirilmiştir. Seçimlerde 57.058.636 seçmen oy kullanmıştır (www.ysk.gov.tr, 2020). Siyasi partiler ve adaylar 30 Mart 2019 tarihi saat 18:00'a dek seçim kampanyası yürütmüștür (www.resmigazete.gov.tr, 2020). Araştırma, seçimlerde oy kullanabilen genç nüfusun yoğun olarak kümelendiği üniversite öğrencilerine yönelik gerçekleştirilmiştir. Bu kapsamda seçim kampanyası sürecinde üniversite öğrencisi olan genç seçmenlerin medya kullanımı çalışmanın konusunu oluşturmaktadır. Bu bağlamda araştırma kapsamında yüzde 95,6 oranında 17 ve 26 yaş aralığındaki üniversite öğrencilerine uygulanan anket çalışması çerçevesinde genç nüfusun seçim dönemlerindeki medya kullanım düzeyleri saptanmak istenmiştir.

\subsection{Amaç ve Önem}

Araştırma kapsamında son dönem seçim kampanyalarında medyanın etkinliğinin ölçülmesi amaçlanırken, karar alma süreçlerinde medyanın ve ilişkili faktörlerin rolü saptanmak istenmektedir. Araştırma çerçevesinde, literatürde seçim süreçlerine ilişkin yer alan çalışmalarda medyanın yerine ilişkin bulgulara katkı sağlanması ve medyanın seçim süreçlerindeki rolüne ilişkin değişimlerin saptanması amaçlanmaktadır. Üniversite öğrencilerine yönelik gerçekleştirilen çalışma, seçim dönemlerinde genç nüfusun medya kullanım düzeylerine ve gençlerin karar alma süreçlerinde etkili olduğu düşünülen bilgi kaynaklarına atfettikleri öneme ilişkin analizler sunmaktadır.

\subsection{Yöntem ve Örneklem}

Çalışma, Kırklareli Üniversitesi, Kütahya Dumlupınar Üniversitesi, Muş Alparslan Üniversitesi, İnönü Üniversitesi, Kocaeli Üniversitesi, Selçuk Üniversitesi, Erciyes Üniversitesi, Karabük Üniversitesi ve Bülent Ecevit Üniversitesi öğrencilerine yönelik gerçekleştirilmiştir. Erişim kolaylı̆̆ sebebiyle seçilen dokuz üniversitede eğitim gören 550 öğrencinin katılımıyla gerçekleştirilen çalışmada anket tekniği uygulanmıştır. 39 sorudan oluşan anket çalışmasında katılımcıların demografik özelliklerini belirlemeyi amaçlayan sorular ve kitle iletişim araçları kullanım sıklıklarını, siyasal bilgi edinme kaynaklarını ve siyasal tercih oluşturmadaki iletişim araç ve yöntemlerinin önem düzeylerini ortaya koyan ölçek (Balcı ve Akar, 2010) kullanılmıştır. Araştırmanın evrenini Türkiye'deki 129 devlet üniversitesinde 2018-2019 eğitim öğretim döneminde, ön lisans (1.749.729.5) ve lisans(3.005.806.5) derecesinde örgün eğitim gören toplam 4.755.536 öğrenci oluştururken (www.yok.gov.tr, 2020), çalışmanın örneklemi ise dokuz devlet üniversitesinde eğitim gören 550 öğrencidir. Seçilen dokuz üniversite, araştırmanın sınırlılığını oluştururken 550 katılımcıdan oluşan örneklem ise istatistiki açıdan yüzde 5 oranında hata payına sahiptir (Baş, 2005: 43). 21 Mart-28 Mart 2019 tarihleri arasında katılımcıların onayıyla gerçekleștirilen anket çalışmasından elde edilen veriler SPSS programında frekans analizi, ANOVA, korelasyon analizi ve T-testi gerçekleștirilerek analiz edilmiştir. 


\subsection{Bulgular}

\section{Anket Güvenilirlik Düzeyi}

Likert ölçeğe ilişkin yapılan güvenilirlik analizinde Cronbach's Alpha değeri, 889 olarak hesaplanmıştır. Sosyal bilimlerde yapılan araştırmalarda mevcut Cronbach's Alpha değeri güvenilir olarak kabul edilmektedir.

\section{Katıımcıların Demografik Özellikleri}

Tablo 1: Katılımcıların Demografik Özellikleri

\begin{tabular}{|c|c|c|c|}
\hline $\begin{array}{l}\text { DEMOGRAFIK } \\
\text { ÖZELLIKLER }\end{array}$ & CINSIYET, YAŞ VE ÜNIVERSITE & SAYI & YÜZDE \\
\hline \multirow{3}{*}{ cinsiYet } & Erkek & 228 & 41,5 \\
\hline & Kadın & 322 & 58,5 \\
\hline & TOPLAM & 550 & 100 \\
\hline \multirow{4}{*}{ YAŞ } & 17-20 Yaş arası & 229 & 41,6 \\
\hline & 21-25 Yaş arası & 299 & 54,4 \\
\hline & 26 ve üzeri yaş & 22 & 4,4 \\
\hline & TOPLAM & 550 & 100 \\
\hline \multirow{10}{*}{ ÜNIVERSITE } & Bülent Ecevit Üniversitesi & 60 & 10,9 \\
\hline & Erciyes Üniversitesi & 55 & 10 \\
\hline & İnönü Üniversitesi & 49 & 8,9 \\
\hline & Muş Alparslan Üniversitesi & 73 & 13,3 \\
\hline & Necmettin Erbakan Üniversitesi & 68 & 12,4 \\
\hline & Karabük Üniversitesi & 63 & 11,5 \\
\hline & Kırklareli Üniversitesi & 65 & 11,8 \\
\hline & Kocaeli Üniversitesi & 49 & 8,9 \\
\hline & Kütahya Dumlupınar Üniversitesi & 68 & 12,4 \\
\hline & TOPLAM & 550 & 100 \\
\hline
\end{tabular}

Araştırma; Bülent Ecevit Üniversitesi (yüzde 10,9), Erciyes Üniversitesi (yüzde 10), İnönü Üniversitesi (yüzde 8,9), Muş Alparslan Üniversitesi (yüzde 13,3), Necmettin Erbakan Üniversitesi (yüzde 12,4), Karabük Üniversitesi (yüzde 11,5), Kırklareli Üniversitesi (yüzde 11,8), Kocaeli Üniversitesi (yüzde 8,9), Kütahya Dumlupınar Üniversitesi (yüzde 12,4) olmak üzere dokuz üniversitede eğitim gören 550 öğrenciye yönelik gerçekleştirilmiştir. Katılımcıların yüzde 58,5'i kadınlardan, yüzde 41,5'i erkeklerden oluşmaktadır. Katılımcıların yüzde 41,6'sı 17-20 yaş aralığında, yüzde 54,4'ü 21-25 yaş aralığında ve yüzde 4,4 'ü 26 yaş ve üzerindedir.

\section{Katılımcıların Kitle İletişim Araçları Kullanım Düzeyi}

Tablo 2: Katılımcıların Kitle İletişsim Araçları Kullanım Düzeyi

\begin{tabular}{|l|l|c|c|c|c|}
\hline KiA & Seçenekler & Sayı & Yüzde & Ortalama & Standart Sapma \\
\hline \multirow{4}{*}{ iNTERNET } & Hiç & 6 & 1,1 & & \\
\cline { 2 - 4 } & Haftada 1-2 gün & 8 & 1,5 & & \\
\cline { 2 - 4 } & Haftada 3-4 gün & 9 & 1,6 & \multirow{2}{*}{4,80} & \multirow{2}{*}{, 641} \\
\cline { 2 - 4 } & Haftada 5-6 gün & 43 & 7,8 & & \\
\cline { 2 - 4 } & Her gün düzenli & 484 & 88 & & \\
\cline { 2 - 4 } & TOPLAM & $\mathbf{5 5 0}$ & $\mathbf{1 0 0}$ & & \\
& & & & & \\
\end{tabular}




\begin{tabular}{|c|c|c|c|c|c|}
\hline KİA & Seçenekler & Sayı & Yüzde & Ortalama & Standart Sapma \\
\hline \multirow{6}{*}{ TV } & Hiç & 171 & 31,1 & \multirow{6}{*}{2,48} & \multirow{6}{*}{1,410} \\
\hline & Haftada 1-2 gün & 160 & 29,1 & & \\
\hline & Haftada 3-4 gün & 93 & 16,9 & & \\
\hline & Haftada 5-6 gün & 36 & 6,5 & & \\
\hline & Her gün düzenli & 90 & 16,4 & & \\
\hline & TOPLAM & 550 & 100 & & \\
\hline \multirow{6}{*}{ GAZETE } & Hiç & 320 & 58,2 & \multirow{6}{*}{1,68} & \multirow{6}{*}{,996 } \\
\hline & Haftada 1-2 gün & 135 & 24,5 & & \\
\hline & Haftada 3-4 gün & 60 & 10,9 & & \\
\hline & Haftada 5-6 gün & 19 & 3,5 & & \\
\hline & Her gün düzenli & 16 & 2,9 & & \\
\hline & TOPLAM & 550 & 100 & & \\
\hline \multirow{6}{*}{ RADYO } & Hiç & 359 & 65,3 & \multirow{6}{*}{1,57} & \multirow{6}{*}{,981 } \\
\hline & Haftada 1-2 gün & 118 & 21,5 & & \\
\hline & Haftada 3-4 gün & 41 & 7,5 & & \\
\hline & Haftada 5-6 gün & 12 & 2,2 & & \\
\hline & Her gün düzenli & 20 & 3,6 & & \\
\hline & TOPLAM & 550 & 100 & & \\
\hline
\end{tabular}

Seçim dıșı normal zamanlarda kitle iletişim araçlarının kullanım düzeylerine bakıldı̆̆ında internet, diğer kitle iletişim araçları arasında en çok kullanılan araç olarak gözükmektedir. İnternet, katılımclar tarafından her gün düzenli $(4,80)$ kullanılmaktadır. Televizyon $(2,48)$ ortalama haftada bir-iki gün izlenirken, gazete $(1,68)$ televizyona göre daha düşük oranda takip edilmektedir. Radyo ise $(1,57)$ diğer kitle iletişim araçları arasında en az takip edilen araçtır. Bu veriler geleneksel kitle iletişim araçlarının takip düzeyinin internete göre oldukça düşük oranda olduğunu göstermektedir. Geleneksel kitle iletişim araçları arasında da televizyon en çok takip edilen araç konumundadır.

\section{Seçim Haberleriyle Günlük İIgilenme Oranı}

Tablo 3: Seçim Haberleriyle Günlük İlgilenme Oranı

\begin{tabular}{|l|c|c|}
\hline Ortalama Dakika & Ortalama & Standart Sapma \\
\hline $30-60$ dakika & 1,84 & 1,82 \\
\hline
\end{tabular}

Seçim haberleriyle günlük ilgilenme oranlarına ilişkin -hiç takip etmiyorum, 0-30 dk., 60 dk., 90 dk., 120 dk., 150 dk., 180 dk., 210 dk., 240 dk., 270 dk., 300 dk. ve daha fazla süre, şeklinde oluşturulan skaladan ortalama değer elde edilmiştir. Bu çerçevede tespit edilen 1,84 ortalama ile katılımcıların seçim haberleriyle günlük ilgilenme oranı 30 ve 60 dakika arasındaki bir zaman dilimini kapsamaktadır.

\section{Oy Verme Tercihinde Etkili Unsurlar}

Tablo 4: Oy Verme Tercihinde Etkili Unsurlar

\begin{tabular}{|l|c|c|}
\hline Oy Tercihinde Etkili Faktörler & Sayı & Yüzde \\
\hline Adayın Kendisi & 225 & 40,9 \\
\hline Adayın Partisi & 156 & 28,4 \\
\hline Medya Gündemi & 24 & 4,4 \\
\hline Siyasal Kampanya Etkinliği & 145 & 26,4 \\
\hline TOPLAM & $\mathbf{5 5 0}$ & $\mathbf{1 0 0}$ \\
\hline
\end{tabular}

Oy tercihinde etkili olduğu varsayılan dört faktöre ilişkin katılım düzeyleri ayrı ayrı belirlenmiştir. Bu çerçevede dört faktör arasında oy verme tercihinde en etkili faktörlerin 
adayın kendisi (yüzde 40,9) ve adayın partisi (yüzde 29,4) olduğu gözükmektedir. Adayın siyasal kampanyada etkinliği, oy verme tercihinde yüzde 26,4 oranında etkili faktörler arasında yer almaktadır. Medya gündemi (yüzde 4,4) ise oy verme tercihinde oldukça düşük bir etkiye sahiptir.

\section{Adaylara İlişkin Bilgi Edinilen Kitle İletişim Araçları}

Tablo 5: Adaylara İlişsin Bilgi Edinilen Kitle İletişim Araçları

\begin{tabular}{|c|c|c|c|c|}
\hline Mecra & Sayı & Yüzde & Ortalama & Standart Sapma \\
\hline İnternet & 411 & 74,7 & \multirow{5}{*}{2,21} & \multirow{5}{*}{0,479} \\
\hline Televizyon & 122 & 22,2 & & \\
\hline Gazete & 13 & 2,4 & & \\
\hline Radyo & 4 & 0,7 & & \\
\hline TOPLAM & 550 & 100 & & \\
\hline
\end{tabular}

Kitle iletişim araçları arasında adaylara ilişkin bilgi edinilen mecra en çok internet olarak gözükmektedir. Katılımcıların yüzde 74,7'si adaylar hakkında internet aracılığıyla bilgi edinmektedir. Bu süreçte televizyon (yüzde 22,2 ) oranında orta düzeye yakın bir bilgi edinme aracıyken gazete (yüzde 13) ve radyo (yüzde 4) adaylara ilişkin bilgi edinilen mecralar arasında en düşük seviyede kullanılan araçlardır.

\section{Siyasal Tercihleri Belirlemede İletişim Araç ve Yöntemlerinin Önem Düzeyi}

Tablo 6: Siyasal Tercihleri Belirlemede İletişim Araç ve Yöntemlerinin Önem Düzeyi

\begin{tabular}{|c|c|c|c|c|c|}
\hline İletişim ve Araç Yöntemleri & Seçenekler & Sayı & Yüzde & Ortalama & Standart Sapma \\
\hline \multirow{6}{*}{ İnternet İçerikleri } & Çok Önemsiz & 29 & 5,3 & \multirow{6}{*}{4,23} & \multirow{6}{*}{1,092} \\
\hline & Önemsiz & 18 & 3,3 & & \\
\hline & Biraz Önemli & 50 & 9,1 & & \\
\hline & Önemli & 152 & 27,6 & & \\
\hline & Çok Önemli & 301 & 54,7 & & \\
\hline & TOPLAM & 550 & 100 & & \\
\hline \multirow{6}{*}{ Televizyon Yayınları } & Çok Önemsiz & 40 & 7,3 & \multirow{6}{*}{4,06} & \multirow{6}{*}{1,180} \\
\hline & Önemsiz & 26 & 4,7 & & \\
\hline & Biraz Önemli & 48 & 8,7 & & \\
\hline & Önemli & 182 & 33,1 & & \\
\hline & Çok Önemli & 254 & 46,2 & & \\
\hline & TOPLAM & 550 & 100 & & \\
\hline \multirow{6}{*}{ Gazete İçerikleri } & Çok Önemsiz & 51 & 9,3 & \multirow{6}{*}{3,41} & \multirow{6}{*}{1,193} \\
\hline & Önemsiz & 61 & 11,1 & & \\
\hline & Biraz Önemli & 158 & 28,7 & & \\
\hline & Önemli & 170 & 30,9 & & \\
\hline & Çok Önemli & 110 & 20 & & \\
\hline & TOPLAM & 550 & 100 & & \\
\hline \multirow{6}{*}{ Radyo Yayınları } & Çok Önemsiz & 116 & 21,1 & \multirow{6}{*}{2,71} & \multirow{6}{*}{1,242} \\
\hline & Önemsiz & 126 & 22,9 & & \\
\hline & Biraz Önemli & 161 & 19,3 & & \\
\hline & Önemli & 95 & 17,3 & & \\
\hline & Çok Önemli & 52 & 9,5 & & \\
\hline & TOPLAM & 550 & 100 & & \\
\hline
\end{tabular}

Siyasal tercihleri belirleme sürecinde etkili olan iletişim araç ve yöntemleri arasında, internet içerikleri ve televizyon yayınları katılımcılar tarafından önemli bulunmaktadır. 
İnternet içerikleri 4,23 oranında önemli bulunurken, televizyon yayınları da 4,06 oranında önemli görülmektedir. Gazete içerikleri, biraz önemli bulunurken $(3,41)$, radyo yayınları ise diğer bilgi kaynakları arasında diğerlerine göre en düşük oranda $(2,71)$ önemli bulunmaktadır.

\section{Seçim Sürecinde Medya Türlerine Göre Takip Oranı}

Tablo 7: Seçim Sürecinde Medya Türlerine Göre Takip Oranı

\begin{tabular}{|c|c|c|c|c|c|}
\hline KIA & Seçenekler & Sayı & Yüzde & Ortalama & Standart Sapma \\
\hline \multirow{6}{*}{ Sosyal Medya } & Hiç & 41 & 7,5 & \multirow{6}{*}{4,215} & \multirow{6}{*}{1,290} \\
\hline & Haftada 1-2 gün & 38 & 6,9 & & \\
\hline & Haftada 3-4 gün & 62 & 11,3 & & \\
\hline & Haftada 5-6 gün & 67 & 12,2 & & \\
\hline & Her gün düzenli & 342 & 62,2 & & \\
\hline & TOPLAM & 550 & 100 & & \\
\hline \multirow{6}{*}{ Yaygın Medya } & Hiç & 94 & 17,1 & \multirow{6}{*}{3,04} & \multirow{6}{*}{1,333} \\
\hline & Haftada 1-2 gün & 100 & 18,2 & & \\
\hline & Haftada 3-4 gün & 138 & 25,1 & & \\
\hline & Haftada 5-6 gün & 124 & 22,5 & & \\
\hline & Her gün düzenli & 94 & 17,1 & & \\
\hline & TOPLAM & 550 & 100 & & \\
\hline \multirow{6}{*}{ Yerel Medya } & Hiç & 155 & 28,2 & \multirow{6}{*}{2,64} & \multirow{6}{*}{1,388} \\
\hline & Haftada 1-2 gün & 121 & 22 & & \\
\hline & Haftada 3-4 gün & 122 & 22,2 & & \\
\hline & Haftada 5-6 gün & 73 & 13,3 & & \\
\hline & Her gün düzenli & 79 & 14,4 & & \\
\hline & TOPLAM & 550 & 100 & & \\
\hline
\end{tabular}

Medya türleri; yaygın medya (ulusal düzeyde yayın yapan TV ve Radyo yayınları ile basılı gazete ve bunların web sayfaları) yerel medya (bölgesel düzeyde yayın yapan TV ve Radyo yayınları ile basılı gazete ve bunların web sayfaları) ve sosyal medya (facebook, twitter, instagram gibi sosyal ağlar) şeklinde sınıflandırılmıştır. Bu çerçevede yerel seçimlerde medya türleri arasında en fazla takip edilen unsur sosyal medya olarak gözükmektedir. Sosyal medya katılımcılar tarafından haftada beş-altı gün $(4,21)$ takip edilmektedir. Türkiye genelinde yayın yapan yaygın medya ise orta düzeyde $(3,04)$ takip edilmektedir. Yerel medya 2,64 oranında, diğer medya türlerine göre en az oranda takip edilmektedir.

\section{Seçim Sürecinde Medya Türlerine İlişkin Önemlilik Düzeyi}

Tablo 8: Seçim Sürecinde Medya Türlerine İlişkin Önemlilik Düzeyi

\begin{tabular}{|l|l|c|c|c|c|}
\hline KiA & Seçenekler & Sayı & Yüzde & Ortalama & Standart Sapma \\
\hline \multirow{4}{*}{ Sosyal Medya } & Çok önemsiz & 28 & 5,1 & & \\
\cline { 2 - 4 } & Önemsiz & 17 & 3,1 & & \\
\cline { 2 - 4 } & Biraz Önemli & 71 & 12,9 & \multirow{2}{*}{4,27} & \multirow{2}{*}{1,120} \\
\cline { 2 - 4 } & Önemli & 95 & 17,3 & \\
\cline { 2 - 4 } & Çok Önemli & 339 & 61,6 & & \\
\cline { 2 - 4 } & TOPLAM & $\mathbf{5 5 0}$ & $\mathbf{1 0 0}$ & & \\
& & & & & \\
\end{tabular}




\begin{tabular}{|c|c|c|c|c|c|}
\hline KİA & Seçenekler & Sayı & Yüzde & Ortalama & Standart Sapma \\
\hline \multirow{6}{*}{ Yaygın Medya } & Çok önemsiz & 41 & 7,5 & \multirow{6}{*}{3,81} & \multirow{6}{*}{1,120} \\
\hline & Önemsiz & 33 & 6 & & \\
\hline & Biraz Önemli & 105 & 19,1 & & \\
\hline & Önemli & 180 & 32,7 & & \\
\hline & Çok önemli & 191 & 34,7 & & \\
\hline & TOPLAM & 550 & 100 & & \\
\hline \multirow{6}{*}{ Yerel Medya } & Çok önemsiz & 75 & 13,6 & \multirow{6}{*}{3,61} & \multirow{6}{*}{1,391} \\
\hline & Önemsiz & 42 & 7,6 & & \\
\hline & Biraz Önemli & 104 & 18,9 & & \\
\hline & Önemli & 130 & 23,6 & & \\
\hline & Çok önemli & 199 & 36,2 & & \\
\hline & TOPLAM & 550 & 100 & & \\
\hline
\end{tabular}

Seçim sürecinde takip edilen medya türleri arasında katılımcılar en fazla sosyal medya kullanımına önem vermektedir. Sosyal medya, seçim sürecinde, 4,27 oranında neredeyse çok önemli seviyesindedir. Yaygın medya 3,81 ve yerel medya 3,61 oranında birbirine yakın bir düzeyde katılımcılar nezdinde önemliliğe sahiptir.

\section{Siyasal Kampanya Sürecinde Beslenilen Kaynaklar}

Tablo 9: Siyasal Kampanya Sürecinde Beslenilen Kaynaklar

\begin{tabular}{|l|c|c|c|c|c|c|c|c|}
\hline & \multicolumn{4}{|c|}{ SEÇENEKLER } & \multicolumn{4}{c|}{ GENEL VERiLER } \\
\hline BiLGi KAYNAKLARI & En Çok & Çok & Orta & Biraz & Hiç & Sayı & Ortalama & S. Sapma \\
\hline Haber Siteleri & 204 & 163 & 104 & 44 & 35 & 550 & 3,83 & 1,194 \\
\hline TV Haberleri & 212 & 146 & 95 & 44 & 53 & 550 & 3,76 & 1,301 \\
\hline Aile ve Yakın Çevre & 180 & 112 & 114 & 74 & 70 & 550 & 3,47 & 1,393 \\
\hline İnternet Reklamları & 140 & 101 & 130 & 74 & 105 & 550 & 3,18 & 1,440 \\
\hline Siyasi Partilerin TV reklamları & 136 & 110 & 115 & 76 & 113 & 550 & 3,15 & 1,460 \\
\hline Youtube İçerikleri & 126 & 115 & 128 & 70 & 111 & 550 & 3,14 & 1,430 \\
\hline Twitter İçerikleri & 125 & 117 & 92 & 80 & 136 & 550 & 3,03 & 1,503 \\
\hline $\begin{array}{l}\text { Seçime özel hazırlanan } \\
\text { internet sayfaları }\end{array}$ & 100 & 104 & 135 & 80 & 131 & 550 & 2,93 & 1,419 \\
\hline Gazete Haberleri & 93 & 110 & 102 & 114 & 131 & 550 & 2,85 & 1,421 \\
\hline $\begin{array}{l}\text { Siyasi Partilerin Resmi } \\
\text { İnternet Sayfaları }\end{array}$ & 83 & 103 & 130 & 84 & 150 & 550 & 2,79 & 1,412 \\
\hline Adayların Web sayfaları & 72 & 74 & 154 & 79 & 171 & 550 & 2,63 & 1,383 \\
\hline Aday Tanıtım Broşürleri & 69 & 81 & 113 & 113 & 174 & 550 & 2,56 & 1,421 \\
\hline Facebook İçerikleri & 55 & 72 & 87 & 95 & 241 & 550 & 2,28 & 1,394 \\
\hline Seçim Büroları & 56 & 53 & 90 & 105 & 246 & 550 & 2,21 & 1,368 \\
\hline
\end{tabular}

Seçim kampanyası sürecinde beslenilen kaynaklar arasında haber siteleri diğer bilgi kayaklarına göre en fazla takip edilen kaynak olarak gözükmektedir. "Çok" düzeyinde takip edilen haber sitelerinden $(3,83)$ sonra TV haberleri $(3,76)$ gelirken, Aile ve Yakın Çevre $(3,47)$, İnternet Reklamları $(3,18)$, Siyasi Partilerin TV reklamları $(3,15)$, Youtube içerikleri $(3,14)$ ve Twitter içerikleri $(3,03)$ orta düzeyde beslenilen kaynaklar arasında yer almaktadır. Seçime özel hazırlanan internet sayfaları $(2,93)$, gazete haberleri $(2,85)$ ve siyasal partilerin resmi internet sayfaları $(2,79)$, adayların web sayfaları $(2,63)$ ve aday tanıtım broşürleri $(2,56)$ de katılımcılar tarafından düşük düzeyde bilgi kaynağı olarak değerlendirilmektedir. Facebook içerikleri $(2,28)$ ve seçim büroları(2,21) ise seçim sürecinde bilgi kaynağı olarak en az beslenilen kaynaklar arasında yer almaktadır. 


\section{Kitle İletişim Araçlarının Kullanım Tercihleri Arasındaki İlişki}

Tablo 10: Kitle İletişim Araçlarının Kullanım Tercihleri Arasındaki İlişki

\begin{tabular}{|l|c|c|c|c|}
\hline & Televizyon & Gazete & Radyo & İnternet \\
\hline \multirow{2}{*}{ Televizyon } & 1 &, $189^{\star \star}$ &, $186^{\star \star}$ &, 019 \\
\hline \multirow{2}{*}{ Gazete } &, $189^{\star \star}$ &, 000 &, 000 &, 660 \\
\hline \multirow{2}{*}{ Radyo } &, $186^{\star \star}$ & 1 &, $244^{\star \star}$ &, 001 \\
\hline \multirow{2}{*}{ Internet } &, 000 &, $244^{\star \star}$ & 1 &,- 064 \\
\hline
\end{tabular}

Normal zamanlarda kitle iletişim aracı kullanımları arasında ilişkilere bakıldığında geleneksel olarak tanımlanan televizyon, gazete ve radyo kullanımları arasında anlamlı bir ilişki bulunmaktadır. İnternet kullanımı ile radyo-televizyon-gazete kullanımı arasında ise istatistiksel açıdan anlamlı bir ilişki bulunmamaktadır.

\section{Seçim Haberleriyle Günlük İlgilenme Oranı ve Bilgi Kaynakları arasındaki ilişki}

Tablo 11: Seçim Haberleriyle Günlük İlgilenme Oranı ve Bilgi Kaynakları arasındaki ilişki

\begin{tabular}{|l|c|c|c|c|}
\hline & TV Yayınları & Gazete İçerikleri & Radyo Yayınları & İnternet İçerikleri \\
\hline Seçim Haberleriyle &, $088^{\star}$ &, 079 &, $101^{*}$ &, $096^{\star}$ \\
Günlük İlgilenme Oranı &, 040 &, 065 &, 017 &, 024 \\
\hline
\end{tabular}

Seçim haberleriyle günlük ilgilenme oranı ile siyasal bilgilenme sürecinde başvurulan kaynaklar arasında ilişkiye bakıldığında; TV yayınları, radyo yayınları ve internet içerikleri arasında istatistiksel açıdan anlamlı pozitif yönlü zayıf bir ilişki vardır. Gazete içerikleri ile seçim haberleri takibi arasında istatistiksel açıdan anlamlı bir ilişki gözükmemektedir.

\section{Aile ve Yakın Çevre ile KİA'lar arasındaki ilişki}

Tablo 12: Aile ve Yakın Çevre ile KİA'lar arasındaki ilişsi

\begin{tabular}{|l|c|c|c|c|}
\hline & TV Yayınları & Gazete İçerikleri & Radyo Yayınları & İnternet İçerikleri \\
\hline Aile ve Yakın &, $372^{\star \star}$ &, $198^{\star \star}$ &, $184^{\star \star}$ &, $460^{\star *}$ \\
Çevre &, 000 &, 000 &, 000 &, 000 \\
\hline
\end{tabular}

Seçim sürecinde beslenilen kaynaklar arasında ön sıralarda yer alan ve geleneksel ilişkilerin bir parçası olarak öne çıkan aile ve yakın çevrenin kitle iletişim araçlarıyla ilişkisi tespit edilmiştir. Bu çerçevede seçim sürecinde bilgi kaynakları arasında aile ve yakın çevrenin kitle iletişim araçları içerikleriyle olan ilişkisine bakıldığında istatistiksel açıdan anlamlı bir ilişki görülmektedir. Aile ve yakın çevre ile seçim sürecinde bilgi edinilen kaynaklar arasında yer alan TV yayınları, gazete içerikleri, radyo yayınları ve internet içerikleriyle istatistiki ilişki anlamlı ve pozitif yönlüdür. İlişki zayıf gözükse de seçmen açısından kitle iletişim araçları çıktıları ve aile-yakın çevreden edinilen bilgi arasında bir etkileşim olduğu gözükmektedir.

\section{Aile ve Yakın Çevre ile Oy Tercihinde Karar Zamanı İlişkisi}

Tablo 13: Aile ve Yakın Çevre ile Oy Tercihinde Karar Zamanı İlişkisi

\begin{tabular}{|l|l|c|c|c|c|}
\hline \multirow{4}{*}{$\begin{array}{l}\text { Aile ve Yakın } \\
\text { Çevre }\end{array}$} & OY TERCiHinDE KARAR ZAMANI & Sayı & Ortalama & F & Sig. \\
\cline { 2 - 6 } & $\begin{array}{l}\text { Seçim dönemi olmasa bile hangi } \\
\text { partiye oy vereceğim zaten bellidir. }\end{array}$ & 256 & 3,64 & \multirow{2}{*}{4,907} & \multirow{2}{*}{, 008} \\
\cline { 2 - 4 } & Seçim Kararı alınıp adaylar belirlendiğinde & 213 & 3,24 & & \\
\cline { 2 - 5 } & Seçim kampanyası sürecinde & 81 & 3,51 & & \\
\hline
\end{tabular}


Seçim kampanyası sürecinde siyasal bilgilenme kaynakları arasında aile ve yakın çevreyi önemli bulan seçmenlerle oy verme tercihinde karar zamanı arasında anlamlı bir ilişki bulunmaktadır. Buna göre siyasal bilgilenme sürecinde aile ve yakın çevreyi önemseyen katılımcıların çoğunluğunun seçim dönemi olmasa bile hangi partiye oy vereceği zaten bellidir. Bu durum geleneksel ilişkilerin ve ideolojik yapının oy tercihinde belirleyici olduğunu gösterirken diğer taraftan seçim kararı alınıp adaya göre oy tercihini belirleyenler de aile ve yakın çevreyi siyasal bilgi kaynağı açısından önemli bulmaktadır. Seçim kampanyası ise oy tercihinde, aile ve yakın çevreyi önemli bulan seçmen için en az önemlidir. Bu durum bir yandan da aile ve yakın çevreyi önemli bulan seçmen için kampanya sürecinin karar vermede düşük oranda etkili olduğunu göstermektedir.

\section{Seçim Haberleriyle Günlük İlgilenme Süresinde Cinsiyet Farklılıkları}

Tablo 14: Seçim Haberleriyle Günlük Illgilenme Süresinde Cinsiyet Farklllıkları

\begin{tabular}{|l|l|c|c|c|c|c|c|}
\hline & Cinsiyet & Sayı & Ortalama & S. Sapma & t & df & Sig. \\
\hline \multirow{2}{*}{$\begin{array}{l}\text { Seçim Haberleriyle } \\
\text { Günlük İlgilenme Oranı }\end{array}$} & Erkek & 228 & 2,04 & 2,168 & \multirow{2}{*}{2,149} & \multirow{2}{*}{548} & \multirow{2}{*}{, 000} \\
\cline { 1 - 7 } & Kadın & 322 & 1,70 & 1,518 & & & \\
\hline
\end{tabular}

Seçim haberleriyle günlük ilgilenme süresine bakıldığında seçim haberleriyle ilgilenme konusunda cinsiyete göre anlamlı bir farklılaşma gözlemlenmektedir. $\mathrm{Bu}$ çerçevede erkekler seçim haberleriyle günde 1 saatten fazla $(2,04)$ ilgilenirken kadınlar ise bir saatten az $(1,70)$ ilgilenmektedir.

\section{Parti ya da Adaya Oy Verme Karar Zamanı ile Oy Tercihinde Etkili Olan Faktörler Arasındaki Karşılaştırmalı Tablo}

Tablo 15: Parti ya da Adaya Oy Verme Karar Zamanı ile Oy Tercihinde Etkili Olan Faktörler Arasındaki Karşılaştırmalı Tablo

\begin{tabular}{|l|c|c|c|c|c|}
\hline & \multicolumn{3}{|c|}{ OY VERMEDE ETKiLi OLAN FAKTÖR } & TOPLAM \\
\hline $\begin{array}{l}\text { Parti Ya da Adaya Oy } \\
\text { Vermede Karar Zamanı }\end{array}$ & Adayın kendisi & Adayın partisi & $\begin{array}{c}\text { Medya } \\
\text { Gündemi }\end{array}$ & $\begin{array}{c}\text { Adayın yaptığı } \\
\text { siyasal kampanya } \\
\text { etkinliği }\end{array}$ & The \\
\hline $\begin{array}{l}\text { Seçim dönemi olmasa } \\
\text { bile hangi partiye oy } \\
\text { vereceğim zaten bellidir }\end{array}$ & $\begin{array}{c}86 \\
(\% 33,6)\end{array}$ & $\begin{array}{c}118 \\
(\% 46,1)\end{array}$ & $\begin{array}{c}10 \\
(\% 3,9)\end{array}$ & $\begin{array}{c}42 \\
(\% 16,4)\end{array}$ & $\begin{array}{c}256 \\
(\% 100)\end{array}$ \\
\hline $\begin{array}{l}\text { Seçim kararı alınıp } \\
\text { adaylar belirlendiğinde }\end{array}$ & $\begin{array}{c}116 \\
(\% 54,5)\end{array}$ & $\begin{array}{c}29 \\
(\% 13,6)\end{array}$ & $\begin{array}{c}7 \\
(\% 3,3)\end{array}$ & $\begin{array}{c}61 \\
(\% 28,6)\end{array}$ & $\begin{array}{c}213 \\
(\% 100)\end{array}$ \\
\hline $\begin{array}{l}\text { Seçim kampanyası } \\
\text { sürecinde }\end{array}$ & $\begin{array}{c}23 \\
(\% 28,4)\end{array}$ & $\begin{array}{c}7 \\
(\% 5,8)\end{array}$ & $\begin{array}{c}42 \\
(\% 5,6)\end{array}$ & $\begin{array}{c}81 \\
(\% 100)\end{array}$ \\
\hline
\end{tabular}

Parti ya da adaya oy vermede karar zamanı ile oy tercihinde etkili olan faktörler arasındaki karşılaştırmalı tabloya bakıldığında, seçim dönemi olmasa dahi hangi partiye oy vereceği belli olan seçmenlerin, adayın partisi (yüzde 46,1) ve adayın kendisinin (yüzde 33,6) oy verme tercihinde belirleyici olduğu gözükmektedir. Adayın yaptığı siyasal kampanya etkinliği(yüzde 16,4) ve medya gündemi(yüzde 3,9) en az belirleyici durumundadır. Diğer taraftan seçim kararı alınıp adaylar belirlendiğinde oy tercihini belirleyenler için oy tercihindeki faktörlerde adayın kendisi(yüzde 54,5) ve adayın yaptığı siyasal kampanya faaliyeti (yüzde 28,6) etkili gözükmektedir. Seçim kampanyası sürecinde oy tercihini belirleyenler ise adayın yaptığı siyasal kampanya etkinliği(yüzde 51,9) ve adayın kendisi (yüzde 28,4) oy tercihinde etkili faktörler olarak belirmektedir. Seçim kampanyası sürecindekarar verenler için medya gündemiyüzde 8,6 oranında etkili faktör olarak gözükürken, adayın partisi (yüzde 5,8) oy tercihinde en az etkili faktör durumundadır. 


\section{Bilgi Edinme Mecraları Arasındaki İlişki}

Tablo 16: Bilgi Edinme Mecraları Arasındaki İlişki

\begin{tabular}{|l|c|c|c|c|c|c|c|c|}
\hline & $\begin{array}{c}\text { Adayların } \\
\text { Web } \\
\text { Sayfaları }\end{array}$ & $\begin{array}{c}\text { Siyasi } \\
\text { Partilerin } \\
\text { Resmi Sayfaları }\end{array}$ & Twitter & Facebook & Youtube & $\begin{array}{c}\text { Seçime Özel } \\
\text { Hazırlanan } \\
\text { internet Sayfaları }\end{array}$ & $\begin{array}{c}\text { Aday tanıtım } \\
\text { Broşürleri }\end{array}$ & $\begin{array}{c}\text { Siyasi } \\
\text { Partilerin TV } \\
\text { reklamları }\end{array}$ \\
\hline Yerel &, $318^{\star \star}$ &, $299^{\star \star}$ &, 055 &, 054 &, 071 &, $250^{\star \star}$ &, $194^{\star \star}$ &, $185^{\star \star}$ \\
Medya &, 000 &, 000 &, 202 &, 206 &, 097 &, 000 &, 000 &, 000 \\
\hline Yaygın &, $224^{\star \star}$ &, $256^{\star \star}$ &, $213^{\star \star}$ &, $150^{\star \star}$ &, $241^{\star \star}$ &, $282^{\star \star}$ &, $255^{\star \star}$ &, $258^{\star \star}$ \\
Medya &, 000 &, 000 &, 000 &, 000 &, 000 &, 000 &, 000 &, 000 \\
\hline Sosyal &, $178^{\star \star}$ &, $160^{\star \star}$ &, $294^{\star \star}$ &, $351^{\star \star}$ &, $293^{\star \star}$ &, $216^{\star \star}$ &, $100^{\star}$ &, $252^{\star \star}$ \\
Medya &, 000 &, 000 &, 000 &, 000 &, 000 &, 000 &, 019 &, 000 \\
\hline
\end{tabular}

Seçim sürecinde bilgi kaynakları açısından önemlilik ilişkisinde, yerel medyayı önemseyenler ile adayların web sayfaları, siyasi partilerin resmi sayfaları, seçime özel hazırlanan internet sayfaları, aday tanıtım broşürleri ve siyasal partilerin TV reklamları arasında anlamlı bir ilişki gözükmektedir. Buna karşın yerel medya ile Facebook, Youtube ve Twitter içeriklerinin önem derecesi arasında istatistiki açıdan anlamlı bir ilişki görünmemektedir. Yaygın medya ve sosyal medyanın seçim sürecinde bilgi kaynağı açısından önemlilik düzeyiyle Facebook, Youtube ve Twitter içerikleri dâhil olmak üzere adayların web sayfaları, siyasi partilerin resmi sayfaları, seçime özel hazırlanan internet sayfaları, aday tanıtım broşürleri ve siyasal partilerin TV reklamları arasında anlamlı bir ilişki gözükmektedir.

\section{Sonuç}

Seçim dönemlerinde seçmenlerin medya kullanım oranları ve bilgi kaynakları arasındaki ilişkilerin tespit edilmesi amaçlanan çalışmanın sonuçları medyanın önemli bilgi kaynakları arasındaki rolünü ortaya koymaktadır. Seçim dönemlerinde medya kullanımının oldukça yüksek oranda olduğu gözükmektedir. Özellikle internet genç nüfus arasında yaygın biçimde kullanılan kitle iletişim aracıyken bunu sırasıyla televizyon, gazete ve radyo izlemektedir. Radyo ve gazete oldukça düşük oranda takip edilen medyalar arasında yer alırken, televizyon geleneksel kitle iletişim araçları içerisinde halen hatırı sayılır bir takipçi oranına sahip gözükmektedir. Bu durum televizyonun siyaset sahnesine girdiğinden beri, seçim kampanyalarında önemli bir araç olduğunu gösteren literatürdeki çalışmaları (Tokgöz, 2010; Temel, 2013; Koçak, 2014; West, 1994/1995; Balcı ve Bor, 2015) desteklemektedir.

Kitle iletişim araçlarının katılımcılar tarafından siyasal tercihlerin belirlenmesi ve seçim sürecinde çeşitlenen önem düzeylerindeki bilgi kaynakları gösterilmesi medya kullanımıyla gerçekleşen seçim kampanyaları açısından önemli gözükmektedir. Medyanın yanı sıra aile ve yakın çevre, adayın kendisi ve siyasi parti de oy verme davranışında etkili faktörler arasında yer almaktadır. Bu bağlamda medya (özellikle internet ve televizyon) bilgi kaynağı olması açısından önemli bulunmakla beraber, karar süreçlerindeki etkisi ideolojik ve çevresel faktörlerin önüne geçememektedir. Ancak aile ve yakın çevrenin siyasal bilgilenme sürecindeki önem düzeyiyle, siyasal bilgilenme sürecinde televizyon ve internetin önemlilik düzeyi arasındaki istatistiki açıdan anlamlı gözüken ilişki, medya mesajlarının dolayımlanarak bir etkileşim sürecine girdiğini göstermektedir. Bir anlamda medyanın dolaylı bir etki sağladığından söz etmek mümkündür. Diğer taraftan seçim kampanyaları ve medya gündeminin karar alma süreçlerinde düşük gösterilen önemlilik düzeyi de siyasal bilgi edinme kaynakları arasında yüksek ve düşük etkiye sahip unsurların birbirlerini destekleyen karmaşık bir denklem sunması açısından seçim kampanyalarının bütüncül bir yaklaşımla ele alınmasını zorunlu kılmaktadır. 
Seçim haberleriyle günlük ilgilenme oranı da yaklaşık bir saatlik zaman dilimini kapsamaktadır. Bu sonuç seçim haberlerine ilişkin medya aracılığıyla gerçekleşen önemli bir ilgi düzeyi olduğunu göstermektedir. Bu duruma cep telefonları, tablet gibi medya içeriklerine kolayca ulaşılabilmesini sağlayan araçların yaygınlaşmasının ve özellikle internetin yoğun kullanılıyor olmasının kaynak teşkil ettiği düşünülmektedir.

Seçimlerin yerel boyutta gerçekleşmesine karşın, yerel medya, yaygın medya ve sosyal medyaya nazaran en az takip edilen mecra olarak gözükmektedir. Bu durum bilgi kaynakları açısından sosyal medyanın yerel unsurları da sarmalayan yönünü gösterirken diğer taraftan yaygın basının da seçim dönemlerinde yerel konulara olan ilgisine işaret etmektedir. Bu bağlamda başta internet olmak üzere ve televizyonun (ulusal ölçekte yayın yapan TV'ler) yerel bölgelerdeki bilgi akışında önemli bir enformasyon kaynağı durumunda olduğunu söylemek mümkündür. Bu sonuçlar seçmenlerin, yerel adaylardan ziyade partinin genel durumunun ulusal medyadan takip edilmesinin bir sonucu olarak değerlendirilebilir.

Araştırmada elde edilen bulgular, genç nüfusun her gün düzenli internet kullanıyor olduğunu ve interneti bilgi edinme kaynakları arasında en üst sırada gösterdiklerini ortaya koymaktadır. Bu durum siyasi partilerin ve adayların özellikle genç nüfusa yönelik seçim kampanyalarında internet ve sosyal medyayı etkin kullanmalarının önemine işaret etmektedir. Seçim dönemlerinde medyanın etkin kullanımı politikacıların başarı elde etmeleri adına bir zorunlulukken, seçmenlerin de doğru tercih yapabilmeleri için medyayı bilinçli takip etmeleri aynı oranda zaruret arz etmektedir. Bu noktada Stuart Hall (2001) 'ın Decoding Encoding adlı çalışmasında ele aldığı üzere insanların mesajı kabul etmesi, ret etmesi ya da müzakere etmesi kampanya sürecindeki davranış biçimini belirgin kılan önemli bir aşamadır.

\section{Bilimsel Etiğe Uygunluk}

Bu çalışma, Erciyes Üniversitesi Sosyal ve Beşeri Bilimler Etik Kurulu'nun 24.03.2020 tarihli toplantısında görüşülmüş ve etik açıdan uygun bulunmuştur.

\section{Kaynakça}

Akyol, Mevlüt. (2015). "Seçim Kampanyalarında Sosyal Medya Kullanımı: Facebook ve 2014 Cumhurbaşkanlığı Seçimleri”. Elektronik Sosyal Bilimler Dergisi 14(55):98114.

Arklan, Ümit ve Akgül, Mahmut. (2013). Sosyal Medya Ortamında İçerik Üretim Süreci ve Etki Eden Faktörler: Sivas Örneğinde Uygulamalı Bir Çalışma, The Journal of Academic Social Science Studies, Volume 6 Issue 6, p. 53-82, June 2013

Aziz, Aysel. (2007). Siyasal İletişim. Ankara: Nobel Yayınevi.

Bal, Enes ve Delal, Özlem. (2019). "Siyasal Bilgilenmede Twitter Kullanımı Üzerine Panoramik Bir Değerlendirme”. Social Sciences 14(3):118-132.

Balcı, Şükrü. (2016). 7 Haziran'dan 1 Kasım’a Türkiye'de siyasal iletişim uygulamaları, Konya: Literatürk Academia

Balcl, Şükrü ve Akar, Hüsamettin. (2010). "Siyasal Bilgilenmede İletişim Araç ve Yöntemlerinin Önem Düzeyi: 29 Mart 2009 Yerel Seçimleri Konya Araştırması". Humanities Sciences 5(2):282-305. 
Balcl, Şükrü ve Bor, Tuğba (2015). "Siyasal Bilgilenmede Televizyonun Önem Düzeyi: Üniversite Öğrencileri Üzerine Bir İnceleme”, Global Media Journal: Turkish Edition, 5/10, 47-70.

Baş, Türker (2005). Anket Nasıl Hazırlanır ? Nasıl Uygulanır ? Nasıl Değerlendirilir ?, Ankara: Seçkin Yayıncılık

Başarır, Murat. (2019). "Siyasal İletișim Sürecindeki Metaforik Üsluba İlişkin Betimleyici Bir Çalışma”. Erciyes İletişim Dergisi 6(1):625-640.

Bayraktutan, Günseli; Binark, Mutlu; Çomu, Tuğrul; Doğu, Burak; İslamoğlu, Gözde ve Telli Aydemir, Aslı. (2014). "Siyasal iletişim sürecinde sosyal medya ve Türkiye'de 2011 genel seçimlerinde Twitter kullanımı”. Bilig (68):59-96.

Blumler, Jay G. ve Kavanagh, Dennis. (1999). "The third age of political communication: Influences and features". Political communication 16(3):209-230.

Borins, Sanford. (2011). “Online Adaydan Online Başkana”. içinde Seçim Kampanyalarında Geleneksel Medya, Internet ve Sosyal Medyanın Kullanımı. Ed. Yusuf Devran. İstanbul: Başlık Yayın Grubu.

Çağlar, Nedret ve Köklü, Pelin Havva. (2017). "Yeni medyanın siyasal iletişim aracı olarak kullanımı: Siyasal partilerin resmi web sitelerine yönelik bir araştırma”. Gümüşhane Üniversitesi İletişim Fakültesi Elektronik Dergisi 5(1):148-173.

Damlapınar, Zülfikar ve Balcı, Şükrü. (2014). Siyasal İletişim Sürecinde Seçimler, Adaylar, Imajlar. Konya: Literatürk Academia.

Gurevitch, Michael; Coleman, Stephen ve Blumler, Jay G.. (2009)."Political communicationOld and new media relationships". The ANNALS of the American Academy of Political and Social Science 625(1):164-181.

Hall, Stuart. (2001). "Encoding/decoding”. Media and cultural studies: Keyworks 2.

İnce, Mustafa ve Koçak, Mevlüt Can. (2018). "The Use of Tv In USA Precidency Electıons As A Mass Media”. Electronic Turkish Studies 13(13).

Kalender, Ahmet. (2000). Siyasal iletişim, seçmenler ve ikna stratejileri. Konya: Çizgi.

Karaçor, Süleyman. (2009). "Yeni iletişim teknolojileri, siyasal katılım, demokrasi”. Yönetim ve Ekonomi: Celal Bayar Üniversitesi İktisadi ve İdari Bilimler Fakültesi Dergisi 16(2):121-131.

Kellner, Douglas. (2011). "Barack Obama ve Ünlü Gösterisi”. Ss. 45-84 içinde Seçim Kampanyalarında Geleneksel Medya, Internet Ve Sosyal Medyanın Kullanımı. Ed. Yusuf Devran. İstanbul: Başlık Yayın Grubu.

Koçak, Mevlüt Can (2014). Siyasal Bilgilenme Sürecinde Televizyonun Rolü ve Etkileri (Konya Örneği). Yüksek Lisans Tezi, Konya: Selçuk Üniversitesi Sosyal Bilimler Enstitüsü

Laswell, Harold. (1960). The structure and function of communication Communication In The Society. Urbana: University of Illinois Press.

McNair, Brain. (2011). An Introduction to Political Communication. New York: Routledge.

Olkun, Emre Osman; Yüksel, Esra ve Akdemir, Gizem Ylldız. (2018). "Sosyal Medya ve Siyasal Katılım: 2017 Referandumunda Bir Saha Araştırması”. Journal of International Social Research 11(60). 
Özkan, Abdullah. (2004). Siyasal İletişim partiler,seçimler,stratejiler. İstanbul: Nesil Yayınları.

Paletz, David L. ve Lipinski, Daniel. (1994). "Political culture and political communication". Working Papers (92).

Ryfe, David Michael. (2001). "History and Political Communication: An Introduction". Political Communication 18(4):407-20.

Strömbäck, Jesper ve Kiousis, Spiro. (2014). “Strategic political communication in election campaigns”. Political communication 18:109.

Temel, Faruk. (2013). "Siyasal Tercihlerin Oluşum Sürecinde Kitle İletişim Araçlarının Rolü”. Selçuk Üniversitesi Sosyal Bilimler Enstitüsü Dergisi (29):239-250.

Temel, Faruk; Önürmen, Onur ve Köprü, Mehmet. (2014). "Seçim Kampanyalarında Dijital Araçlar ve İnternetin Yeri: Üniversite Öğrencilerine Yönelik Bir Araștırma”. Global Media Journal: Turkish Edition 5(9).

Tokgöz, Oya. (2008). Siyasal İletişimi Anlamak. Ankara: İmge Yayınevi.

Tokgöz, Oya. (2010). Seçimler Siyasal Reklamlar ve Siyasal İletişim. Ankara: İmge Yayınevi

Tunca, Elif Asude ve Avtürk Koldaş, Nurten. (2019). "İletişim Perspektifinden Siyasal İletişim ve Seçim Kampanyaları". Insan ve Toplum Bilimleri Araştırmaları Dergisi 8(4):2785-2809.

Ünlü, Çiğdem Yasemin. (2018). "Seçim Kampanyaları ve Politik/Kamusal Konuşmaların Gelişimi Üzerine Bir Literatür İncelemesi." Global Media Journal: Turkish Edition $8(16)$.

Vural Akıncı, Z. Beril ve Bat, Mikail. (2009). "Siyasal Seçim Kampanyalarında Yeni İletişim Teknolojileri ve Blog Kullanımı: 2008 Amerika Başkanlık Seçimlerine Yönelik Karşılaştırmalı Bir Analiz". Journal of Yaşar University 4(16):2745-2778.

West, Darrell M. (1994/1995). Television advertising in election campaigns. Political Science Quarterly, 109, 789-809.

www.amerikaninsesi.com. (2020). “Amerika'da Başkanlık Seçim Kampanyaları ve Medya". Amerika'nin Sesi / Voice of America - Turkish. Geliş tarihi 13 Nisan 2020 (https://www.amerikaninsesi.com/a/amerikada-bakanlk-secim-kampanyalar-vemedya-148735595/1207566.html).

www.gemius.com.tr. (2020). "Yerel Seçim 2019: İnternet meydanında en büyük kalabalığı kim topladı?" Gemius Turkey. Geliş tarihi 13 Nisan 2020 (http://www.gemius.com. tr/974/yerel-secim-2019-nternet-meydaninda-en-buyuk-kalabalgi-kim-topladi. html).

www.resmigazete.gov.tr. (2020). Geliş tarihi 14 Nisan 2020 (https://www.resmigazete. gov.tr/eskiler/2018/12/20181213M1-1.pdf).

www.yok.gov.tr. (2020). Geliş tarihi 14 Nisan 2020 (https://istatistik.yok.gov.tr/).

www.ysk.gov.tr. (2020). Geliş tarihi 14 Nisan 2020 (http://www.ysk.gov.tr/tr/ istatistik/5644). 


\title{
Media use of the Young Population in The Election Periods: March 31, 2019 Local Elections in Turkey
}

\author{
Faruk Temel (Asst. Prof. Dr.)
}

\section{Extended Abstract Introduction}

In Turkey, a survey has been performed for university students in the campaign process of local elections held on March 31, 2019, and the results obtained have been evaluated. The research is carried out by applying the survey technique, which is a quantitative approach. Within the scope of the research, it is aimed to determine the relations of the young population with the media in the election processes and to measure the effectiveness of the information sources in the election campaigns in line with the family and the close environment and the media.

The research answers to such questions as "What is the media usage rate during the election periods?", "What is the importance given to media tools in decision making processes?", "What are the sources of information in the selection process?", What is the significance given to these sources of information?" What are the effective factors in determining the voting decision?", and "What is the relationship between these factors?"

The research population is formed with a total of 4,755,536 students studying at the 129 state universities in Turkey, while the sample consists of 550 students studying at the nine universities.

\section{Findings}

The usage levels of mass media are determined on a 5-Point Likert Scale based on such options regular every day, five-six days a week, three-four days a week, two days a week and never use. When looking at the usage levels of mass media in non-election times, the internet (4.80) seems to be the most used tool among other mass media (Television (2.48), newspaper (1.68), and radio (1.57).

Average value is obtained from the scale, formed with0-30 min., $60 \mathrm{~min}$., $90 \mathrm{~min} ., 120$ min., 150 min., 180 min., 210 min.,240 min., 270 min., and more than 300 minutes, which is related to the involvement rates in election news. With an average of 1.84 determined within this framework, the daily involvement of the participants in the election news covers a 30-minute and 60-minute time frame.

Among the mass media (television $22.2 \%$, newspaper $13 \%$, and radio $4 \%$ ), the media where information about candidates is obtained is mostly seen as the Internet $(74.7 \%)$.

Among the communication tools and methods that are effective in the process of determining political preferences, internet contents (4.23) and television broadcasts (4.06) are important by the participants. Newspaper contents are somewhat important (3.41), while radio broadcasts are the least important (2.71) among other sources of information.

Among the media types in local elections (common media 3.04, local media 2.64), social media (4.21) is the most followed elements five or six days a week. 
Among the media types followed during the selection process, the participants attach great importance to social media contents in terms of information source. Social media is almost at a very important level of 4.27 in the selection process. mainstream media (3.81) and local media (3.61) are less important than social media.

Among the information sources fed during the election campaign, news sites seem to be the most followed source compared to other information sources. While TV news (3.76) comes after the news sites (3.83) followed by "very" level, Family and Immediate Circle (3.47), Internet Ads (3.18), TV ads of Political Parties (3.15), Youtube contents (3.14), and Twitter contents (3.03) are among the medium-fed sources.

In the selection process, there is a statistically significant positive relationship between the family and immediate environment with TV broadcasts, newspaper contents, radio broadcasts and internet contents. Although there is a weak relationship, it is seen that there is an interaction between the mass media and the family and the immediate environment.

There is a significant relationship between the sources of political information during the election campaign between the voters who find the family and the immediate environment important and the decision time in voting preference. Accordingly, it is already clear which party will vote for the majority of the participants who care about the family and the immediate environment in the political information process, even if there is no election period. The election campaign, on the other hand, is at least important for the voter who finds the family and the immediate environment important in the oting choice.

When looking at the comparison between the decision time and voting factors in voting for the party or the candidate, the voters who are certain to vote for which party, even if there is no election period, the party of the candidate (46.1 percent) and the candidate himself (33.6 percent) seems to be more effective in voting preference than others. The candidate's activity in political campaign (16.4 percent) and media agenda (3.9 percent) are the least determining.

\section{Conclusion}

It seems that the use of media in the election periods is quite high. While the Internet is a mass communication tool that is widely used among the young population, it is followed by television, newspaper, and radio respectively. While radio and newspaper are among the media that are followed at a very low rate, television still seems to have a considerable follower rate among traditional mass media. Since this has entered the political scene of television, it supports the studies in the literature that show that it is an important tool in election campaigns.

The determination of the political preferences of the mass media by the participants and showing them as a source of information in the election process seems to be important for the election campaigns that are carried out by using the media. On the other hand, the family and the immediate environment, the candidate himself and the political party are among the influential factors in voting behavior. In this context, although media (especially Internet and television) is important in terms of being an information source, its effect on decision processes cannot prevent ideological and environmental factors. However, the statistically significant relationship between the importance level of the family and the immediate environment in the political information process and the 
importance of television and the internet in the political information process shows that the media messages are mediated and entered into an interaction process. In a sense, it is possible to mention that the media has an indirect effect.

The daily involvement rate of the election news also covers about an hour of time. This result shows that there is a significant level of interest in media related to election news. It is believed that the widespread use of tools that enable easy access to media contents such as mobile phones and tablets and especially the internet being used extensively lead to this situation.

Although the elections take place at a local level, local media seems to be the least followed medium compared to mainstream media and social media. While this situation shows the direction of social media that covers the local elements in terms of information sources, it also points to the interest of the mainstream media on local issues during the election periods. In this context, it is possible to say that the television (TV's broadcasting nationally) and especially the internet are important sources of information in the information flow in the local regions. These results can also be evaluated as a result of the prevalence of ideological voting behavior in terms of voters and accordingly, the follow of the general outlook of the party in the national media rather than the local candidates.

Keywords: Political Communication, Election Campaigns, Media, Young Population, University Students. 